Uşak Üniversitesi Sosyal Bilimler Dergisi (2008) 1/2, 125-141

\title{
TÜRK BANKACILIK SISTEMINDE REKABET STRATEJILERİ VE YAYILIM SÜRECI
}

\author{
Ramazan ARSLAN*
}

\section{Özet}

$\mathrm{Bu}$ çalışmada Özel Sermayeli Ticari bankaların rekabet stratejileri ve yayılım süreci incelenmiştir. Rekabet stratejilerinin yayılımında, "rekabetçi", temeller söz konusu olmasına rağmen, özelikle sektörde "kurumsal nitelikteki baskıların" ağırlıklı bir rol oynadığı görülmektedir. Kurumsal nitelikteki bu baskılar uygulamada bankalar açısından benzerlikler oluşturmaktadır. Özel Sermayeli Ticari Bankalar açısından bu benzerlikler üç alan üzerinde değerlendirilmektedir. Bunlar; ürün, süreç ve yapısal bazda gerçekleşmektedir. Özel Sermayeli Ticari Bankaların uyguladıkları stratejilerin yayılımında, örgütlerin içinde bulunduğu çevrenin sürekli olarak değişiyor olması ve örgütler üzerinde baskı oluşturmasının payı çok büyüktür. Benzer şekilde, yeni stratejilerin doğuşu ve benimsenmesinde örgütlerin yaşam eğrisi içindeki yeri de önemlidir. Yine kurumsal bir çevrede yaşayan bankaların benzer uygulamalara yönelme isteği, sektörde devletin kural ve düzenlemelerinin sıkça değişerek örgütler üzerinde oluşturduğu baskıdan kaynaklanmaktadir.

Anahtar Kelimeler: Türk Bankacılık Sistemi, Rekabet Stratejisi, Kurumsal Çevre, Yayılım Süreci.

\section{Abstract}

This paper examines the competition strategies and spreading process of Commercial Banks with Private Capital. It is observed that, although "competitive" basics can be claimed to exist, it is "pressures with an institutional nature" which plays a dominant role in spreading of competition strategies. These institutional pressures display similarities in terms of banks in the application. Such similarities are assessed in three areas as regards Commercial Banks with Private Capital, which are product-based, process-based and structural-based. The fact that the environment in which organizations is doing business is constantly changing, which imposes pressure on organizations, has an essential part in the arising and spreading of strategies employed by Commercial Banks with Private Capital. Likewise, their place on the life-line of organizations is also critical in arising and internalization of new strategies. The desire of the banks doing business in an institutional environment to orient towards similar practices stems from the fact that

\footnotetext{
* Yrd. Doç. Dr. Uşak Üniversitesi, İktisadi ve İdari Bilimler Fakültesi, İşletme Bölümü
} 
governmental rules and regulations change often enough to create excessive pressure on organizations.

Key Words: Turkish Banking System, Competition Strategy, Institutional Environment, Spreading Process.

\section{Giriş}

Günümüzde işletmeler çok hılı değişen koşullar karşısında ve büyük belirsizlikler içinde faaliyetlerini sürdürmektedir. Yaşanılan bu değişim; bir taraftan, işletmeleri kendine uymaya ve sürekli yenilik yapmaya zorlarken; diğer taraftan, yoğun bir rekabetle karşı karşıya bırakmaktadır. $\mathrm{Bu}$ nedenle işletmeler varlıklarını devam ettirebilmek için, hem çevre değişikliklerini önceden öngörmek, hem de güçlü bir rekabet ortamında üstünlük sağlamak zorunda kalmıştır. Bu durum ise rekabet edebilme gücüne ve üstünlüğüne bağl1 görünmektedir. Bugün işletmeler için "rekabet üstünlüğ̈̈" yaratmanın yolu doğru bir strateji seçiminden geçer. Rekabete dayanan ekonomik bir ortamda strateji, her şeyden önce yeniliği, ilerlemeyi ve çevre ile karşılıklı uyum içinde olmasını sağlayarak, meydana gelen değişiklikleri kontrol altına alma amacı taşır.

\section{Rekabet Anlayışının Evrimi}

Rekabet "işletmelerin varlıkların sürdürmek ve başarılı olmak için diğer işletmelerle yaptıkları yarış" olarak ifade edilir (Özkara, 1997: 47). Bu yarış işletmelerin varlıklarını koruyabilmek için yaptıkları ya da yapacak oldukları faaliyetlerin tümünü kapsar. Bu bağlamda işletmeler rekabeti; ham, basit ve gerçekçi olmayan biçimlerde tanımlarlar. Halbuki işletmeler rakiplerinin kabiliyetlerini ve reaksiyonların tam olarak tahmin edemezler. Öyle ki, bazıları rekabetin gerçek kaynaklarını ifade etmekte bile yetersiz kalırlar (HENDERSON, 1983: 63) Rekabeti anlamanın en iyi yolu "doğal" ve "stratejik" rekabeti birbirinden ayırmaktan geçer. Doğal rekabete göre, mevcut bir ortamda en güçlü olan hayatta kalır. Bu nedenle işletmeler aynı pazarda aynı ürünleri bilinen rutin yöntemlerle üretmezler. Hatta işletmelerin varlıklarını sürdürebilmeleri, her işletmenin rakiplerine göre nasıl farklı bir üstünlük sağlayacağına bağlıdır (HENDERSON, 1981: 11). Başka bir ifade ile doğal rekabet; düşük riskli küçük deneme yanılma hareketlerinin gözlendiği ve faydalı görülen uygulamaların zamanla yerleștirildiği rekabet etme anlayışıdır $\mathrm{Bu}$ yönüyle evrimseldir (COHEN, 1988: 147). Oysa stratejik rekabet devrimseldir, özü gereği rekabet ilişkilerini değiştirecek büyük değişimleri arar. $\mathrm{Bu}$ nedenle stratejik rekabet hiçbir şeyi şansa birakmaz (HENDERSON, 1981: 2-5). 
Zaman içersinde rekabete ilişkin bakış açılarındaki bu değişim incelendiğinde beş temel evreden söz edilebilir. Bunlar; üretim, maliyet, kalite, hız ve değer yaratma şeklinde sıralanabilir (Özkara, 1997: 50).

\section{A) Üretim Ve Maliyete Dayalı Rekabet}

Endüstri devriminin ilk yıllarında üretim ve arz yetersizliği söz konusu olduğu için, pazarlara üreticiler egemen olmuştur (Özkara, 1997: $50)$. Bu dönemde rekabet üstünlüğünün temel kaynağı üretim hacmi olurken, rekabetin şekillendiği alan ise, iç pazarlardır. $\mathrm{Bu}$ nedenle iç pazarlarda üretim artışını sağlayan işletmeler, henüz doymamış olan pazarlardan daha fazla pay alabilmişler. Ancak rakiplerin çoğalması ile birlikte durum farklılaşarak, maliyet düşüklügü yeni bir üstünlük aracı olarak ortaya çıkmıştır (Kavrakoğlu, 1994: 79). Bu dönemin rekabet anlayışında; amaç; büyüyen pazar firsatlarını değerlendirmek ve pazarlardan daha fazla pay alabilmek, strateji; büyüme, araçlar; üretim artışını sağlayan etkenlik ve verimlilik ilkeleri ile satış artırıcı pazarlama tekniklerini kullanmak, yapı ise; merkezcil, hiyerarşik yapı oluşturmak şeklinde ifade edilebilir (Özkara, 1997: 55).

\section{B) Ürün Pazar Genişlemesine Dayalı Rekabet}

$\mathrm{Bu}$ evrede pazarların genişlemesi ve yeni ürün ya da hizmet çeşitlerinin ortaya çıkması, işletmeleri rekabet anlayışı yönüyle yeni bir değişime zorlamıştır. Çünkü yeni pazarlardan pay alabilmek için pazarlamanın sunduğu araçlar yetersiz kalmıştır. Bu nedenle işletmeler sadece pazarlama araçlarından değil, diğer tüm işlevlerin bir bütün olarak uygulanmasını öneren araçlara yönelmişlerdir. $\mathrm{Bu}$ bağlamda üretim ve maliyet boyutunu, pazarların yapısıyla bütünleştiren stratejik yönetim, rekabetçi üstünlüğün sağlanmasında yeni bir araç olarak uygulanma başlanmıştır (Dinçer, 1998: 185). Bu dönemde rekabetçi stratejiler oluşturmanın temelini, pazar fırsatlarının belirlenmesi için yapılan çevre analizi ve işletmenin bu firsatları değerlendirebilecek kaynaklara sahip olup olmadığı ile ilgili yapısal analizler oluşturur (Williams, 1992: 65). Bu modelde önemli olan çevre koşullarına uyum sağlamayı kolaylaştıracak en uygun stratejilerin belirlenmesi ve uygulamada strateji-yap1 uyumunun sağlanması yaşamsal bir önem taşımaktadır (Tekin ve Güleş, 2000: 155).

$\mathrm{Bu}$ dönemin rekabet anlayışında amaç; büyüyen pazar firsatlarını değerlendirme ve pazardan daha fazla pay alma, strateji; büyüme, araçlar; çevre analizi ve yapısal analiz, yapı; matrisk ve holding yapıları oluşturmak şeklinde ifade edilebilir (Özkara, 1997: 51). 


\section{C) Kalite Ve Hıza Dayalı Rekabet}

1980'li yıllardan bu tarafa rekabetin niteliğini ve kurallarını değiştiren pek çok gelişme söz konusudur. Bu evrede arz ve talep dengesinin ilk kez arzın artması biçiminde gerçekleşmesi, çok sayıda üreticinin göreceli olarak daha az tüketiciyi kazanabilmek için kıyasıya bir rekabetle karşı karşıya bırakmıştır. Yine bu evre, rekabet üstünlüğü sağlamada kalitenin önemli bir stratejik araç olduğunun, ancak etkili olarak kullanılmadığı bir dönemi gösterir (Yüksel ve Özkara, 1999: 7). Bu dönemde Micheal Porter işletmelerin rekabet edebilmeleri için maliyet liderliği, farklılaşma ve niş pazarlara yönelme gibi yöntemleri uygulamaları gerektiğini savunmuştur. Porter'a göre bir işletme; düşük maliyet ve farklılaşma gibi iki tür rekabet üstünlüğüne sahiptir. Bunlar işletmenin değer zincirindeki faaliyetleri rakiplerine göre daha ucuz ve daha benzersiz yapma yeteneklerinden kaynaklanır (Daker ve Wiley, 1988: 204). Başka bir ifade ile işletme ya bilinen mal/hizmeti en düşük fiyattan satmak ya da müşterinin daha fazla ödemeyi kabul edeceği bir farklılaştırma yapmak zorundadır (Dinçer, 1997: 73). Değer zinciri işletmelerin içsel fonksiyonlarının üstünlüğü ve bu fonksiyonlar arasındaki sinerjiyi ilgilendirir. Çünkü farklılaşmayı yaratan bu sinerji dir (Eren, 1997: 166). Başka bir ifade ile değer zincirini oluşturan, temel faaliyet alanıdır. Ancak değer zinciri yalnızca içsel fonksiyonları değil, arz edicilerden dağıtım kanalları ve müşterilere kadar uzanan öğeleri de kapsar. Bunlar; satın alma, hammadde ve malzeme stok, üretim, satış ve pazarlama, dağıtım ve tüketici gibi hizmetlerdir. Ayrıca insan kaynakları yönetimi, ar-ge çabaları ve alt yapı çalışmaları da bu öğelerin kapsamındadır (Dinçer, 1997: 72). Ancak pazarların küreselleşmesi işletmeleri, belirli ürünler, rakipler ve pazarlar üzerinde odaklanma konusunda pek çok zorlukla karşı karşıya bırakmıştır. Çünkü rakipler, yerel ve ulusal olmaktan çok, uluslararası rakip olarak ortaya çıkmaktadır. Rekabet edilen pazarlar da, ulusal ve uluslararası pazar olarak değişmiştir.

1990’lı y1llar ise, tümüyle kaliteye yönelişin odak noktası olmuştur. Kalitenin bir rekabet stratejisi olarak ortaya çıkması, işletme çevresinin değişen bir bakış açısıyla yeniden değerlendirilmesini zorunlu kılmıştır. Yine rekabetçi üstünlüğü geliştirmek için yüksek kaliteyi uygulamak yalnızca bir farklılaşma stratejisi olarak değil, aynı zamanda düşük maliyet stratejisini de beraberinde getirmiştir. Düşük maliyet ve yüksek kaliteyi gerçekleştiren işletmeleri diğerlerinden farklı kılan özellik ise, "sonuç alma hızı" olarak görülmektedir. Buna göre pazarların gelişmesini hızla algılayabilmek, yeni pazarlara hızla girebilmek, yeni ürünleri üreterek müssteriye sunabilmek, müşteriye hızla hizmet vererek isteklerini hızlı bir şekilde karşılayabilmek günümüzde temel rekabet ölçütü olarak kabul edilmektedir Kalitenin rekabet stratejisi olarak ortaya çıkması, işletme çevresinin değişen bir bakış açısıyla değerlendirilmesini zorunlu kılmıştır. Buna göre kaliteye yönelen işletmeler; 
endüstriden rekabete, pazarlardan müşterilere, örgütsel işlevlerden süreçlere yönelmişlerdir.

$\mathrm{Bu}$ dönemin rekabet anlayışında amaç; müşteri tatmini, strateji; kalite ve hız, araçlar; toplam kalite yönetimi ve işletme süreçlerinin yeniden düzenlenmesi, yapı; yalın, takım çalışmasına dayalı yapıları oluşturmak şeklinde ifade edilebilir (HAMEL ve PRAHALAD, 1996: 29).

\section{D) Değer Yaratmaya Dayalı Rekabet}

Günümüzde rekabetin ulaştığı boyut diğer bütün evreleri de kapsamaktadır. Ancak bu evre, bugünün koşullarına uyum sağlamayı kolaylaştıracak bir rekabet anlayışından çok, geleceğin rekabet kurallarını oluşturan pazar lideri konumunu sürdürecek bir rekabet anlayışını öngörmektedir (Barney, 2001: 18). Geleceğe yönelik rekabet modeli bugünün değil, geleceğin koşullarını tahmin ederek, yaratıcı bir düşünceyle farklılıklar yaratmaya dayanır. Yeni rekabet anlayışının özellikleri şunlardır.

\section{Değer Yaratma}

İşletmeler sattıkları ürün ya da hizmet ile tanınırlar. Çünkü müşteriler ürün ya da hizmetleri yarattığı değer ve fayda için satın alırlar. Dolayısıyla başarılı olmak isteyen bir işletme ürün ya da hizmetlerin niçin ve nasıl kullanıldığını bilmesi gerekir. Hatta değer yaratmak sadece maddi anlamda bir ürün ya da hizmeti ortaya koymak değildir. Bu nedenle kalite ve maliyet gibi geleneksel değer yaratma öğelerinin yanında insana ve çevreye özen gösteren, yaratıcılık gibi destekleyici öğelerin de bulunması gerekir. Değer yaratan bir işletmenin odak noktası; yenilik; kalite, verimlilik, etkenlik ve yapılması beklenen başarma yeteneği, denetim; maliyet denetimi, strateji ve gerçekleşenleri bilme yeteneği, özen; müşteriye, iş görene ve çevreye özen, yaratıcılık; yeni değerler üretme şeklinde sıralanabilir.

\section{2. Öz Yeterlilik}

İşletme açısından ürün ve hizmetlerinin alternatifleri karşısında sürdürülebilir bazda tercih edilmelerini sağlayabilmek rekabet edebilme açısından önemli bir yetenektir. Bu ise, bir işletmeyi diğerlerinden ayıran özel bilgi ve beceri kaynakları olarak nitelendirilen öz yeterlilikle sağlanabilir. Çünkü bu bilgi ve beceri ya da kaynaklar müşteriler için yüksek değere sahip ürün ve hizmetler üretmek için özel ve taklit edilmesi güç öz yeteneklere dönüşür (Özkara, 1997: 55-56).

\section{Zaman}

İşletmeler açısından rekabet büyük ölçüde müşteri etrafinda şekillenmektedir. $\mathrm{Bu}$ husus işletmeleri müşteri odaklı yapılanmaya yöneltmekte ve müşteri ilişkilerini öne çıkartmaktadır. Dolayısıyla müşteri 
değerini odak noktası kabul eden işletmeler, müşterilerinin istek ve beklentilerine daha hılı yanıt verme konusunda yoğunlaşmak zorunda kalmışlardır. Hatta işletmelerin bu süreç zamanını azaltarak daha çok müşteri kazanmak istemesi onlara önemli bir rekabet üstünlüğü sağlamıştır.

\section{Ağlar Oluşturma}

Küresel rekabet ve hızlı teknolojik gelişmeler, işletmeleri esnek örgüt yapılarına yöneltmektedir. Ağlar örgüt içi ya da örgüt dışı ilişkilerin işbirliği temeline dayandırılmasıyla ortaya çıkar. A $\breve{g}$ yapılar bir ürün ya da hizmeti üretebilmek için gerekli kaynakları, değer zincirinin değişik noktalarında bulunan farklı işletmelerden sağlayarak kullanırlar. Ayrıca ağ yapılar gerekli kaynakların tümünü ellerinde bulundurmak yerine, en iyi olan diğer işletmelerden sağladıkları için değişmelere daha hızlı yanıt verebilirler.

Rekabet anlayışındaki bütün bu değişme ve gelişmeler her işletmenin kendi rekabet modelini oluşturmasını, benzersiz özellikler, farklı ürünler ve farklı yöntemler geliştirerek geleceğin rekabet kurallarını kendilerinin belirlemesi gerektiğini ortaya koymuştur. İşletmeler açısından bu farklı1ık; rekabet üstünlüğünün sürdürülebilir olması ve tüm stratejilerin küresel boyutta düşünülmesi ya da uygulanması gibi özellikleri de taşıması gerekmektedir (Özkara, 1997: 59).

\section{Türk Bankacılık Sistemi}

Ülkemizde bankacılık sistemi özellikle son 20 yıl içersinde gelişme göstermesine rağmen, geçmişi 19. yüzyıla kadar uzanan köklü bir bankacılık geleneğine dayanır. Özellikle 1980 yılında başlayan ve ekonomimizi radikal bir biçimde etkileyen süreç, doğal olarak bankaları da çok yakından etkilemiştir. Bu dönemde uygulanmaya başlanan serbest piyasa ekonomisi her sektörde olduğu gibi, "bir hizmet sektörü olan" bankacılık sektöründe de kendini hissettirmiştir (İpçi ve Karan, 2001: 33). Bugün ülkemizde faaliyet gösteren bankalar gerek mali yapıları, gerekse kurumsal yapıları itibariyle göz ardı edilemeyecek bir seviyeye ulaşmıştır. Bu dönemde gerçekleştirilen reformlar bankacılık ürün ve hizmetlerinin çeşitlenmesine ve yenilenmesine, kurumsal altyapı gelişmelerinin hızlanmasına ve bankacılık sektörünün mali sistemdeki payının hızla artmasına yol açmıştır (Soysal vd, 1991: 25-26).

Türk Bankacılık Sisteminde, bankaların kuruluş amaçlarına göre değişen ve kanunlarla şekillenen farklı faaliyet alanları söz konusudur. Bu farkl11ı̆̆a rağmen bankaların yerine getirdikleri temel işlevler; "eldeki paranın muhafaza edilebileceğ $i$ güvenli bir yer sağlamak, tedavüldeki paranin toplanmasi ve ödenmesi işlemlerini yerine getirmek, ticari senetleri uskonto veya tahsil etmek, iştiraklerde bulunmak, çek ve akreditif muameleleri yapmak, müşteri adına menkul kıymet alım satımı yapmak, kefalet ve teminat mektubu vermek, kiralık kasa hizmeti vermek, seyahat çeki 
ve kredi kartı gibi konularda danışmanlı yapmak, iş adamlarına banka referans mektubu vermek, Bağkur, S.S.K primi, vergi tahsil işlemlerini yapmak, elektrik, su, doğalgaz, PTT, ev kirası vb. işlemlerin tahsil ve tediyesini" yapmak şeklinde sıralanabilir (Şakar, 2000: 20).

\section{A) Özel Sermayeli Ticari Bankalar}

Türk Bankacılık Sisteminde faaliyette bulunan bankalar; sermayelerine, faaliyetlerine, amaçlarına ve işlevlerine göre sinıflandırılabilir (Takan, 2001: 12). Bu sinıflandırma yapılabilecek sınıflandırma ölçütlerinden sadece bir kaçıdır.

Özel Sermayeli Ticari Bankalar; "faaliyet süresi, sermayesi, aktif büyüklüğ̈̈, şube sayısl, IMKB'de işlem görmesi” gibi özellikleriyle Türkiye'de faaliyette bulunan bankalar içersinde sektörde önemli bir yere sahiptir (T.B.B., 2002: 11-12). Ayrıca çağdaş bankacılığın gerektirdiği bütün hizmetleri vermekte olan bu bankalar, sektördeki "yenilik ve uygulamalart" belirlemede öncü konumda olan büyük ölçekli bankalar olarak nitelendirilmektedir. Özel Sermayeli Ticari bankaların sektör içindeki payı \%61 oranındadır. Ayrıca sektördeki toplam aktiflerin \%56'sını, toplam mevduatın \%61'ini ve toplam kredilerin de \%61'ini oluşturmaktadır. Yine toplam aktif büyüklüklerine göre 20 milyar doların üzerinde aktif büyüklüğüne sahip 1, 10-20 milyar dolar arasında olan 2, 5-10 milyar dolar arasında olan 4 bankadan 3'ünü "Özel Sermayeli Ticari Bankalar" oluşturmaktadır (Yazgan, 2002: 13-19). Başka bir deyişle sistem üzerinde diğerlerine göre baskın durumdadırlar. Genel olarak "Özel Sermayeli Ticari Bankalar" merkez bankalarının ve kalkınma bankalarının bankacılık işlevleri dışında kalan tüm fonksiyonları yerine getirebilmektedir. $\mathrm{Bu}$ bankalar mevzuata uygun olarak; finansal araçların alım ve satımı, kambiyo, türevsel işlemler, menkul kıymet aracılığı, yüklenim, yatırım danışmanlığı ve sigortacılik faaliyetleri de yapabilmektedir (İpçi ve Karan, 2001: 34).

Özel Sermayeli Ticari Bankaların faaliyet alanlarından kaynaklanan kendilerine özgü bir yönetim ve organizasyon yapıları olmasına karşın, bu yapılar bankalar arasında farklılık gösterebilmektedir. Ayrıca özel yasalarla kurulmuş bankalar dışındaki tüm bankalarda bulunması zorunlu olan organlar bankalar kanununca da belirlenmiștir (Alparslan, 2001: 4-7). Bankalar ana hatlarıyla "Genel Müdürlük, Bölge Müdürlükleri ve Şubelerden" oluşan bir organizasyon yapısına sahiptirler. Anonim şirket statüsündeki diğer işletmelerde olduğu gibi, Özel sermayeli Ticari bankalarda da yönetim kurulu hissedarlar adına bankayı yönetmek ve temsil etmek görevini üstlenmiştir. Yönetim kurulu tarafından alınan kararların 
yerine getirilmesi ve bankanın olağan işlerinin yönetimi Genel Müdürlük ve Bölge Müdürlüklerince yerine getirilir (Uzkesici, 1994: 29). Yine Özel Sermayeli Ticari Bankalar Türk Bankacılık sisteminde kuruluş olarak köklü bir geçmişe sahiptirler. Bu bankalar sermaye kökenleri itibariyle yerli sermayeye sahip olup, bir Holding bünyesinde faaliyet göstermektedir. Ülkemizde "Özel Sermayeli Ticari Bankalar", ekonomik ve sosyal faaliyetlerin sürdürülmesi sürecinde, özellikle finans sektöründe oldukça önemli bir yere sahiptir.

\section{B) Ticari Bankalarda Rekabet Stratejileri}

Özel Sermayeli Ticari Bankalar rekabeti, "bankacılık sektöründeki tüm bankalar arasında özgürce ekonomik kararlar verilebilmesini sağlayan, mevzuata uygun bir yarış" olarak kabul ederler. Bu yarış içerisinde oyunun kurallarını "yazll kurallar" ve "yazılı olmayan" yerel ve uluslararası uygulamalardan oluşan "teamüller" belirlemektedir. Özel Sermayeli Bankalar için rekabet, serbest piyasa ekonomisi içerisinde sürdürdükleri faaliyetlerde kendi menfaatlerinin yanında, toplumun menfaatlerinin de gözetilerek yaptıkları ya da yapacak oldukları faaliyetlerin tümünü kapsar. Bir bütün olarak bakıldığında bu faaliyetler, yüksek standartta mali sağlamlık, müşteriye hizmet, çalışanların profesyonelliği, iş ahlakı, kurum üyeliği ve kârlılığa bağlı kalarak; doğru, dengeli ve örnek bir biçimde hissedarların, müşterilerin, çalışanların ve toplumun çıkarlarına hizmet etmek şeklinde gerçekleşir. Bu nedenle özel sermayeli ticari bankaların pek çoğu stratejiyi “müziksiz bir savaş şarkısı” olarak nitelendirmektedir.

Bankalar için strateji belirlemede temel işlev; önceliklerin belirlenmesi, kaynakların dağılımı ve sorumlulukların saptanması şeklindedir (Davis, 1994: 46). Bu süreçte dış baskılar bankaları seçim yapmaya zorlar ve uzun dönemli bir eylem planı hazırlamaya yöneltir. Bu eylemleri gerçekleştirmede asıl amaç; piyasa payı, hacim ve kâr hedeflerinin bir karışımından oluşur. Bankalar bu çerçevede müşterilerinin kafalarında hızla çoğalan, rakipleri karşısında onları farklı kılan özellikleri ile ortaya çıkaracak bir strateji ile meşruiyet sağlamaya sürecine yönelirler.

Özel Sermayeli Ticari Bankalar bütün uygulamalarında; strateji, yapı ve süreçlerin insana ve insan ilişkilerinin oluşturduğu değerler sistemine özen gösterecek şekilde, rekabet üstünlügü sağlamaya yönelmektedirler. $\mathrm{Bu}$ nedenle kalitenin bankalar tarafından bir rekabet stratejisi olarak algılanmasi, işletme çevresinin değişen bir bakış açısıyla yeniden değerlendirilmesini gerektirmiştir. Bankalar bu çerçevede gerek geleneksel hizmetler bağlamında, gerekse yenilik anlamında uyguladıkları stratejilerde bir takım düzenlemeler yapmak zorunda kalmışlardır. Çünkü bilgi teknolojisindeki yoğun ve hızlı gelişmeler müşteri taleplerinde pek çok konuda değişimi beraberinde getirerek rekabetin artmasına neden olmuştur. Başlangıçta 
bankalarda geleneksel hizmetler; mevduat faiz oranları, kredi faiz oranları, havale işlemleri gibi yerine getirmek için benimsenen bilgisayar teknolojisi, daha sonraları bankalarda sistemin vazgeçilmez bir öğesi haline getirmiştir. Buna göre bilgisayar teknolojisiyle bankacıllk hizmetleri hem kesintisiz olarak 24 saatlik bir zaman dilimi içerisinde verilebilir duruma gelmiştir. Ayrıca geleneksel bankacılık hizmetlerinin ötesinde "Elektronik bankacılık, Ev ve Ofis bankacıllğgl, Kredi Kartları, Otomatik Para İslem Makineleri (ATM), Portföy Yöneticiliği, Menkul Klymet ve Yabancı Para Alım ve Satımı gibi" pek çok konuda yeni hizmetler verilmeye başlanmıştır. Bankalarda kullanılan teknolojik araçlardaki gelişmeler, uzun dönemde hem teknolojik yeniliklerle ortaya çıkan yeni bankacılık hizmetlerini ortaya çıkarmış, hem de verimliliği artırarak maliyetleri düşürmüştür. Başka bir ifade ile bankalar ürün ve hizmet özellikleri, satı̧̧ ve dağıtım kanalları, marka ve maliyet üstünlüğü ile yenilik stratejilerini benimsemek zorunda kalmışlardır. $\mathrm{Bu}$ bağlamda Özel sermayeli Ticari bankalar izledikleri stratejide üstünlük sağlayacak olan "hız" ve "komple hizmet" anlayışına yönelmişlerdir. Özel Sermayeli Ticari Bankalar artan ve yoğunlaşan rekabet koşulları karşısında; teknoloji yönelimli, yaratıcı, özgün ve yeni stratejiler uygulamaktadırlar. Bu stratejiler, daha çok bankalarla ilişkili olan tüm kurum ve kuruluşların beklenti ve baskıları doğrultusundan gerçekleşmektedir. $\mathrm{Bu}$ nedenle "benzersiz" ve "müşteriye-özel" ürün ya da hizmet üretme ve bunun içinde yaratıcılık önemli bir özellik olarak karşımıza çıkmaktadır. Özel Sermayeli Ticari Bankalarda "ürün yenileştirme stratejileri” genellikle şu biçimlerde ortaya çıkmaktadır. Bunlar; ürün ve hizmetleri çeşitlendirme, mevcut hizmet gruplarını tamamlayıc1 nitelikte yeni hizmetler sunma, hizmet paketi sunumları ve ürün varyasyonları şeklindedir (Gilbert, 1994: 32-34).

Özel Sermayeli Ticari Bankalarda yenilik oluşumuna bir bütün olarak baktığımızda Şekil 1'de durum daha iyi anlaşılacaktır. 


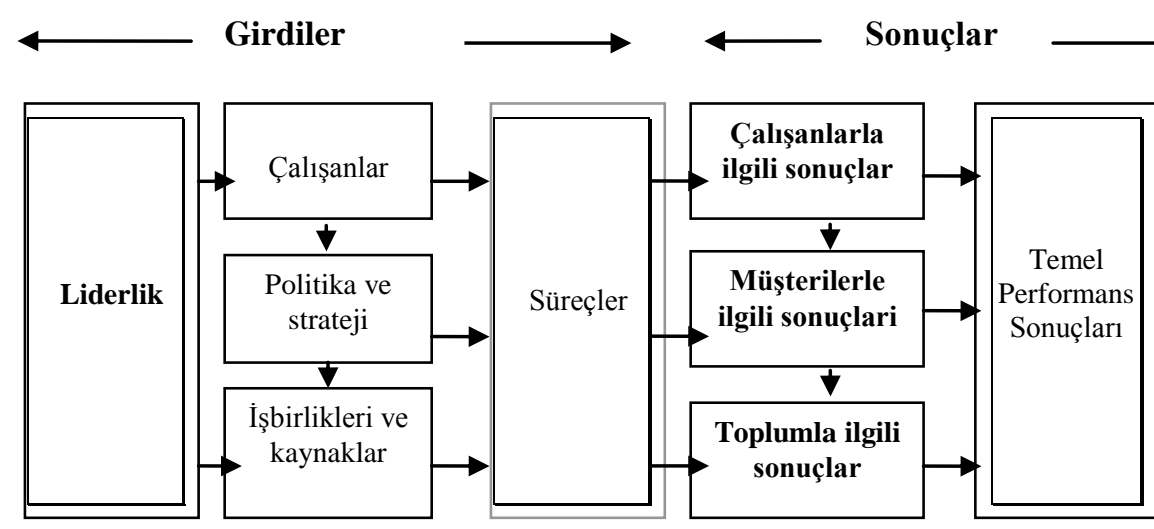

Yenilikçilik ve Öğrenme

Şekil 1: Özel Sermayeli Ticari Bankalarda Yenilik Olușturma Modeli (TÜSİAD, 2002: 79)

Özel Sermayeli Ticari Bankalar açısından rekabet büyük ölçüde müşteri etrafında şekillenmektedir. Bu durum ticari bankaları müşteri odaklı yapılanmaya yöneltmekte ve müşteri ilişkilerini ön plana çıkartmaktadır. $\mathrm{Bu}$ nedenle ticari bankalar açısından rekabetin temel boyutları; maliyetleri düşürmek ve teknolojik yeteneği geliştirmek şeklinde gerçekleşmektedir. Bu nedenle bankalar maliyetlerin düşürülmesi teknolojik yeteneğin geliştirilmesi konusunda yeni organizasyon yapılarına ve iş yapma biçimlerine yönelmişlerdir. Özel Sermayeli Ticari Bankaların teknolojik yeteneklerini geliştirmeleri onlara geleneksel anlamda verdikleri bireysel ve kurumsal bankacılık hizmetlerinde maliyet, hizmet çeşidi ve hız olarak büyük avantajlar sağlamaktadır. Ticari bankalarda bu durum mevcut pazara açılabilmeyi daha da kolaylaştırarak pazar paylarını artırmaktadır. $\mathrm{Bu}$ bağlamda Özel Sermayeli Ticari Bankalar mevcut ürün ve hizmetlere yeni fonksiyonlar katarak iyileştirme ve yeni ürün ve hizmetler geliştirerek çeşitlendirme gibi yenilik stratejilerini uygulamaktadırlar (Oksay, 2003: 65).

\section{C) Yapısal Eşbiçimlilik}

Türkiye'de faaliyette bulunan bankalara bir bütün olarak batkımızda, Özel Sermayeli Ticari Bankaların faaliyet gösterdiği örgütsel alanda onları eşbiçimli olmaya yönelten öğeleri şöyle sıralayabiliriz.

-Bankaların faaliyetleri toplumun tüm kesimlerini ilgilendirmesi nedeniyle bankaların bankacılıkla ilgili kanun ve kurallara uymak zorunluluğu vardır. Bankaların iradesi dışında oluşan ve uymaları zorunlu 
olan yasalar, hükümet politikaları ve ekonomik koşullar bankaların faaliyetlerini yönlendiren ve sınırlayan ve onları eşbiçimli olmaya yönelten zorlayıcı nitelikteki kurumsal baskılar olarak karşımıza çıkmaktadır.

Özel Sermayeli Ticari Bankalar açısından zorlayıcı eşbiçimliliğin kaynağında; hükümet düzenlemeleri ve kanuni yükümlülükler söz konusudur. Türkiye'de bankacılık faaliyetleri; "Bankalar Kanunu, B.B.D.K., T.C.M.B. Kanunu ve Sermaye Piyasası Kanunu olmak üzere Borçlar Hukuku, Türk Ticaret Kanunu, Medeni Kanun, Klymetli Evrak Kanunu, İcra Iflas Kanunu, Vergi Kanunları, T.C.M.B. ve T.C. Başbakanlık Hazine ve Dış Ticaret Müsteşarlı̆̆ı, Bankacılık Genel Müdürlüğ̈̈nün çıkarmış olduğu genelgeler" gibi pek çok düzenleme ile şekillenmektedir. Bu nedenle Özel Sermayeli Ticari Bankalar yap1 ve uygulamalarını bu yasal mevzuat çerçevesinde gerçekleştirmek zorundadır.

Bu bağlamda, Özel Sermayeli Ticari Bankalar "mevduat kabul etme ve iştiraklerine kredi verme gibi" pek çok konuda yasalar çerçevesinde hareket ederler. Yine, ticari bankalar üzerinde etkin bir denetimin sağlanabilmesi için her bankanın belirli dönemlerde yayınlamak zorunda olduğu "faaliyet raporlarl" ve "finansal raporlar gibi" mali tabloların belirli usul ve mevzuata göre bağımsız denetçiler tarafından yerine getirilmesi gerekir. Ayrıca Bankalar Kanunu ile diğer yasal mevzuat çerçevesinde hazırlan bu raporlar; Banka Yönetim Kuruluna ve B.D.D.K. Başkanlığına mutlaka gönderilmek zorundadır (Yüksel vd., 2002: 21-32).

Bütün bu örgütsel işlemler; Tek Düzen Muhasebe Sistemi ve Uluslararası Bankacılık Muhasebe standartları çerçevesinde yerine getirilmektedir. Diğer yandan örgütsel işlemlerinin pek çoğunu; son teknoloji ürünleri olan POS terminali, KIOKS, WAP telefonu, cep bilgisayarı, görüntülü telefon ve İnternet gibi benzer teknolojik araçlar kullanarak sunmaktadır. Bütün bu uygulamalar Bankaların yap1 ve uygulamalarında benzerlikler oluşturmaktadır (Atılgan, 1994: 12-16).

-Özel Sermayeli Ticari Bankalar açısından normatif eşbiçimliliğin kaynağında; profesyonelleşme yatar. Geçmişten günümüze profesyonel bir meslek dalı haline gelen bankacılığın kendine özgü bazı uygulamaları söz konusudur. Normatif eşbiçimliliği oluşturan iki kaynak vardır.

Birincisi, ticari bankalarda çalışan üst düzey yöneticilerin benzer dünya görüşünü veren eğitim almalarıdır. Sektörde üst düzey yönetici olarak görev yapan CEO'lar (Chief Executive Officer) üst düzey yöneticiler; daha çok lisans düzeyinde işletme eğitimi almış ve bunu finans alanında yaptıkları lisansüstü çalışmalarla tamamlayan bireyler oluşturmaktadır. Özel Sermayeli Ticari bankalarda uygulama ve yenilikleri ortaya koyan üst düzey yöneticiler, gerek yurt içinde gerekse yurt dışında sektörle ilgili alanında 
eğitim almış profesyonel yöneticilerden oluşmaktadır (YKB, 2007: 6-8). Bu yöneticiler aynı zamanda sektörde karşılaşılan sorunlarla ilgili genel kabul görmüş bir takım standart çözümleri de beraberinde taşımışlardır. $\mathrm{Bu}$ standart davranışlar yöneticilere mesleki eğitim seminerlerinde veya lisans/lisansüstü eğitimlerle aktarılmıştır.

İkincisi, sektörde ticaret bankacığının uzmanlaşmış bir uygulama niteliği kazanmış olması ve çevresinde meşruiyet arayışının bir sonucu olarak, bankacılık mesleğinin profesyonelleşmiş olması bankalar arasında eşbiçimliliği artırmaktadır. Bankalar arasında "bankacılık mesleğinin gelişmesi, bankalar arasındaki dayanışmanın temini ve haksız rekabetin kaldırılması amactyla gerekli kararların alınması ve uygulanması" amaciyla oluşturulan Türkiye bankalar birliği sektörde normatif eşbiçimliliğin diğer bir kaynağıdır.

Yine bu bağlamda ticaret bankalarını üye oldukları "ICC 500 Kuralları" da, üye olan bankaları bağlayan ve uluslararası ticaretin tanım ve kurallarını, farklı ülkelerdeki bankalar arasındaki faaliyetleri düzenleyen (ülkeler ve bankalar arasındaki uygulama farklılıklarını gidermeyi ve yanlış uygulamalar sonucu bankaların ve müşterilerinin zarar görmesini engellemeyi amaçlar) bu anlaşma, tüm bankaların uymak zorunda oldukları normatif bask1lardandır. FITCHRTINGS ve MOODY'S gibi uluslararası derecelendirme kuruluşlarının bankalara verdikleri notlar da bu bağlamda değerlendirilebilir.

Diğer taraftan, toplumda fon arz eden ve fon talep eden taraflar arasında birleştiricilik ve aracılık rolü oynayarak yatırım ve tasarruf işlevlerini gerçekleştiren bankaların aynı zamanda karlılık ve verimlilik ilkelerini amaç edinmiş olmaları, mesleki ve örgütsel alanda etik ilkelerine bağlı olarak çalışmaları zorunluluğunu getirmektedir. Türk bankacılık sektörünü oluşturan bankalar, gerek birbirleri, gerek müşterileri, gerekse de çalışanları ve diğer kurumlar arasındaki her türlü iş ve işlemlerde uygulanmak üzere, bankacılık etik ilkelerini belirlemişlerdir. Bu bağlamda bankalar, etik ilkelerin geliştirilmesi ve gerektiğinde değişiklikler yapılmasını sağlamak üzere, Türkiye Bankalar Birliği Yönetim Kurulu'na diledikleri zaman yeni öneriler sunabilmektedir.

Etik ilkelerin temel amacı; bankacılık mesleğine toplumda mevcut saygınlık duygusunun sürekliliğinin sağlanması, meslek onuru olarak adlandırılan bu saygınlık duygusunun geliştirilerek sürdürülmesi ve bankacılık sektöründe istikrar ve güvenin korunmasına yöneliktir. Bu bağlamda bankalar arasında etik ilkeleri, bankacılık sisteminin büyütülmesi, bankacılık hizmet kalitesinin arttırılması, kaynakların en iyi şekilde kullanılması, bankalar arasında haksız rekabetin önlenmesi amaçlarından yola çıkarak; bankaların gerek kendi aralarında ve diğer kurumlarla, gerekse 
müşteri ve çalışanları ile olan ilişkilerini de düzenler nitelik kazanarak, sektörde eşbiçimliliğin kaynağını oluşturmaktadır.

-Son olarak, belirsizliğin yüksel olduğu bir çevrede faaliyet gösteren örgütler arasında taklitçi eşbiçimliliğin artmasıdır. Ülkemizde zaman zaman ekonomik ve politik anlamda yaşanan belirsizlikler ticari bankalar arasında da taklitçi eşbiçimliliği doğurmaktadır. Ticari bankalar arasında bu tür bir eşbiçimlilik belirsizlik ortamında başarılı bankaların uygulamalarının model alınmasından ya da sektörde kurumsallaşmış bir uygulama biçiminin düşünülmeden uygulanmasından kaynaklanmaktadır. $\mathrm{Bu}$ bağlamda ülkemizde güçlü bir sermaye piyasasının oluşmamış olması nedeniyle bankaların yüksek bir enflasyonist ortamda yüksek bir döviz kuru ve faiz yükü ile faaliyetlerini sürdürmeleri, sektörde köklü bir geçmişi olan başarılı bankaların strateji, yapı ve uygulamalarının başka bankalar tarafından modellenmesini ortaya çıkarmıştır.

Yine son yıllarda sektörle ilgili yenilikler ve hukuki düzenlemeler Türk Bankacılığı için yeni olanaklar sunarak, ticaret bankalarını rekabetçi bir piyasa ortamına sürüklemiştir. Özellikle A.T.M.ler ve kredi kartları gibi teknolojik yenilikler bütün bankalar arasında taklit edilir hale gelmiştir. $\mathrm{Bu}$ da bankaların yapı ve uygulamaları arasında taklitçi eşbiçimliliği her geçen gün daha çok artırmaktadır. Bankaların kredi kartları, elektronik bankacılık uygulama ve hizmetleri konusundaki benzerlikleri de bunu göstermektedir. $\mathrm{Bu}$ da Türk bankacılık sisteminin yüksek seviyede homojenlik taşıyan, saydam bir endüstri alanı olduğunu göstermektedir. Bu nedenle büyük başarı kazanan yeni bankacılık ürün ve hizmetlerinin bir başka banka tarafından taklit edilme süresinin en fazla altı ay olduğu belirtilmiştir. Bu süre bankalar arasında yaşanan yetişmiş uzman personelin transferiyle birlikte daha kısa sürebilmektedir.

Ayrıca üst düzey yöneticilerin sektördeki uygulamaların gideceği yön hakkında belirttikleri görüşler arasında da benzerlikler söz konusudur. $\mathrm{Bu}$ bağlamda yapılan çalışmalar; tüm kurumların başarısının ve bireysel olarak katılımların ölçülebileceği açıkça tanımlanmış kurumsal stratejinin oluşturulmasıyla mümkün olabileceğini göstermektedir.

\section{Rekabet Stratejilerinin Yayılım Süreci}

Özel Sermayeli Ticari Bankaların uyguladıkları stratejilerin doğuşunda ve yayılımında örgütlerin içinde bulunduğu çevrenin sürekli olarak değişiyor olması ve örgütler üzerinde baskı oluşturmasının payı çok büyüktür. Özellikle ülkemizde güçlü bir sermaye tabanının oluşmamış olması, buna bağlı olarak güçlü sermaye tabanına sahip az, ancak büyük bankaların faaliyet göstermesi önemli bir belirleyici olarak karşımıza çıkar. Benzer şekilde, yeni stratejilerin doğuşu ve benimsenmesi açısından 
örgütlerin yaşam eğrisi içindeki yeri de önemlidir. Yine kurumsal bir çevrede yaşayan bankaların benzer uygulamalara yönelme isteği, sektörde devletin kural ve düzenlemelerinin sıkça değişerek örgütler üzerinde oluşturduğu baskıdan kaynaklanmaktadır. Ayrıca, Kuzey Amerika, Japonya ve Avrupa'daki uygulamalarda ülkemizdeki Özel Sermayeli Ticari Bankaların uyguladıkları stratejilerin yayılımında etkili olabilmektedir.

Görüldüğü gibi, bankaların uyguladıkları stratejilerin benimsenmesinde çok sayıda neden etkili olabilmektedir. Bunlar; bankaların faaliyette bulunduğu pazarın koşulları, kurumsal nitelikteki baskılar ve bankaların kendine özgü birtakım özellikler süreçte etkili olmaktadır (Erken, 2002: 9-15) Bu bağlamda, rekabet stratejilerinin yayılım sürecinde; "rekabetçi” temeller söz konusu olmasına rağmen, özelikle sektörde "kurumsal nitelikteki baskıların” oyunun kurallarını ve yayılımını belirlemede daha ağırlıklı bir rol oynadığı görülmektedir.

Kurumsal nitelikteki bu baskılar uygulamada bankalar açısından benzerlikler oluşturmaktadır. Özel Sermayeli Ticari Bankalar açısından bu benzerlikler üç alan üzerinde değerlendirilebilir. $\mathrm{Bu}$ benzerlikler ürün bazında, süreç bazında ve yapısal bazda söz konusu olmaktadır. Ürün ve süreç bazında teknolojik yeniliklerin oluşturmuş olduğu hizmetler bireysel ve kurumsal anlamda bütün hizmetleri kapsamaktadır. Bu bağlamda bireysel bankacılıkla ilgili kredi kartı uygulamalarında, aile bankacılığı hizmetlerinde ve elektronik bankacılık hizmetlerinde benzerlikler söz konusudur. Yine, portföy yönetimi ve menkul kıymet alım ve satımı konusunda verilen hizmetler üzerinde de büyük benzerlikler söz konusudur.

$\mathrm{Bu}$ hizmetlere bağlı olarak yapısal anlamda benzerliklerde söz konusudur. Ticari bankaların hemen hepsinde müşteri odaklı bir organizasyon yapısı uygulanmaktadır. Özellikle yeni ürünler için yeni süreçlerin geliştirilmesi noktasında yeniden yapılanma çabaları ağırlıklı olarak yer almaktadır. Yine bu bağlamda, yönetim ve süreçlere yönelik ISO 9000 gibi kalite sertifikaları konusunda benzer çalışmalar söz konusudur. Ayrıca Özel Sermayeli Ticari Bankaların uyguladıkları stratejilerin doğuşunda ve yayılımında, örgütlerin içinde bulunduğu çevrenin sürekli olarak değişiyor olması ve örgütler üzerinde baskı oluşturmasının payı çok büyüktür. Benzer şekilde, yeni stratejilerin doğuşu ve benimsenmesinde örgütlerin yaşam eğrisi içindeki yeride önemlidir. Yine kurumsal bir çevrede yaşayan bankaların benzer uygulamalara yönelme isteği, sektörde devletin kural ve düzenlemelerinin sıkça değişerek örgütler üzerinde oluşturduğu baskıdan kaynaklanmaktadır. 


\section{Sonuç}

Türk Bankacılık Sisteminde bankaların yapı ve uygulamalarında yeni kavram ve tekniklerin kullanımı artmaktadır. Bu yayılım aynı Özel Sermayeli Ticari Bankalar arasında olduğu gibi, farklı örgütsel alanlardaki bankalar arasında da görülebilmektedir.

Türkiye'de kurumsal çevrenin bankalar üzerinde oluşturduğu eşbiçimlilik oldukça önemli büyüklüktedir. Bu nedenle bankaları yalnızca teknik çevrelerin talepleri çerçevesinde değerlendirmek doğru değildir. Bankaları benzer yapıları benimsemeye iten nedenler rekabetçi temellere dayanmakla birlikte, benimseme sürecinde kurumsal baskılar daha büyük oranda etkili olabilmektedir. Bankaları eşbiçimli olmaya yönelten kurumsal baskılar; zorlayıcı, normatif ve taklitçi eşbiçimlilik mekanizmalarıyla gerçekleştirmektedir. $\mathrm{Bu}$ üç mekanizma içerisinden olumlu ve etkili eşbiçimlilik mekanizmasının taklitçi eşbiçimlilik olduğu görülmektedir. Model alınarak taklit edilen bankaların strateji, yapı ve uygulamaları daha çok teknolojik gelişme, yönetici transferleri ve iş değiştirme gibi nedenlerle gerçekleştirilmektedir. Türk Bankacılık Sisteminde genel kabul görmüş strateji, yap1 ve uygulamaların taklitçi eşbiçimlilik baskısıyla yayılması rekabeti yoğunlaştırmaktadır. Bu durumda bankalar farklı yeniliklerin peşine düşmektedirler. Çünkü herkesin kullandığı yöntemlerle rekabetçi üstünlük sağlamak olanaksız bir hale gelmiştir. Ayrıca Özel Sermayeli Ticari Bankaların uyguladıkları stratejilerin doğuşunda ve yayılımında örgütlerin içinde bulunduğu çevrenin sürekli olarak değişiyor olması ve örgütler üzerinde baskı oluşturmasının payı çok büyüktür.

\section{Kaynaklar}

ALPARSLAN, Melike, "Son Dönemde Bankacılık Alanında Gerçekleştirilen Yasal ve Düzenleyici Değişiklikler 1999-2001", Bankacılar Dergisi, Türkiye Bankalar Birliği, S.39, 2001.

ATILGAN, Turan, "İşletmelerin Dış Çevreye Uyumunda Kurumlaşma Eğilimleri”, 2. Yönetim Kongresi, Dokuz Eylül Üniversitesi İşletme Fakültesi Yayınları:1, Kuşadası, 1994.

BARNEY, J.B., Gaining and Sustaining Competitive Advantage, M.A, Second Edition, Reading, Addison- Wesley, 2001.

BONO, Edward De, Rekabet Üstü (Sur Petition), (Çev: Lale ÖZEL), Remzi Kitapevi, İstanbul, 1996.

COHEN, William A., "Competitive Analysis", The practice of Marketing Manegement, , Macmillan, New York, 1988. 
DAKER, David A., WILEY, John, Strategic Market Management, 2. Ed., USA, 1988.

DAVIS, Steven, Mükemmel Bankacılık, Çev: Azer ÖNAL, İstanbul, 1994.

DİNÇER, Ömer, Stratejik Yönetim ve İşletme Politikası, 5. Bask1, Beta Yayınları, İstanbul, 1998.

EKREN, Nazım, "Ekonomi Yönetiminin Performansı: Stratejik Değişim ve Yenilenme İhtiyacı",Active Bankacılık ve Finans Makaleler II, Grand THORNTUN, İstanbul, 2002.

EREN, Kasım, Avrupa Birliğinde ve Türkiye'de Bankacılık, Beta Yayınları, İstanbul, 1997.

GILBERT, T. J., "Choosing An Innovation Strategy: Theory and Practice", Business Horizons, C.37, S.6, (November-December), 1994.

HAMEL, Gary, PRAHALAD, C.K., Geleceği Kazanmak: Yarının Pazarlarını ve Endüstrinin Kontrolünü Yakalamak İçin Keşfedilen Stratejiler, (Çev: Zülfü DİCLELİ), İnkılap Yayınları, İstanbul, 1996.

HENDERSON, Bruce D., "Strategic and Naturel Competition", İnstern, C.W.and Stalk Gjr. Perspective on Strategy, Ed. John WILLEY, Newyork, 1998.

HENDERSON, Bruce D., "The Anatomy of Competition", Journal Of Marketing, C.7, No:11, 1983.

HENDERSON, Bruce D., "Understanding The Forces of Strategic and Naturel Competition", Journal Of Bussines, Strategy, Winter, 1981.

İPÇİ, Mustafa, KARAN, Mehmet Baha, "21. Yüzyıl Eşiğinde Türkiye'de Bankacılık Sisteminin Yapısı, Verimliliği ve Sanayi Sektörüne Katk1ları", ASOMEDYA, Mart 2001.

KAVRAKOĞLU, İbrahim, Toplam Kalite Yönetimi, Kalder Yayınları No:2, 2.Bask1, İstanbul, 1994.

OKSAY, M. Serhan, "Türk Bankacılık Sisteminin Gelişiminin, Dünya Bankacılık Sistemindeki Gelişmeler Işığında Değerlendirilmesi ve Günümüze Yansıyan Yapısal Sorunların Tespiti: 1980-1990 Dönemi”, Banka Maliye ve Ekonomik Yorumlar, S.1, Y.40, Ocak 2003.

ÖZKARA, Belkıs, "Rekabet Modellerinin Değişimi ve Sanayi İşletmelerinde Bir Araştırma”, Çukurova Üniversitesi İktisadi ve İdari Bilimler Fakültesi Dergisi, C.7, S.1, Adana, 1997. 
ÖZKARA, Belkıs, Evrimci ve Devrimci Örgütsel Değişim, Afyon Kocatepe Üniversitesi, Afyon, 1999.

PRAHALAD, C.K., HAMEL, G, "Strategy As A Field of Study: Why Search for A New Paradigm?", Strategic Management Journal, V.15, 1994.

SOYSAL, Muzaffer, TOPRAK, Meral, TANYAŞ, Mehmet, Bankacılık sektöründe Bilgisayar Kullanımı, M.P.M. Yayınları NO: 452, Ankara, 1991.

ŞAKAR, Hakan, Genel Bankacilık Bilgileri, Strata Yayıncılık, Yayın No:4, İstanbul, 2000.

TAKAN, Mehmet, Bankacıllk Teori Uygulama ve Yönetim, Nobel Yayınevi, 1. Bask1, Ankara, 2001.

TEKINN, Mahmut, GÜLEŞ, Hasan, Değişen Dünyada Teknoloji Yönetimi, Mart, 2000. Eylül, 2002.

TÜRKIYY BANKALAR BİRLİ̆İ, Türk Bankacilık Sistemi 2001,

TÜSİAD, Yeni Rekabet Stratejileri ve Türk Sanayisi, Türk Sanayicileri ve İşadamları Derneği, İstanbul, 2002.

UZKESİCI, Nuray, Modern Banka Yönetimi ve Organizasyonu, Anadolu Üniversitesi Yayınları, No:784, Eskişehir, 1994.

WILLIAMS, Jeffrey R., "How Sustainable is Your Competitive Advantage?", California Mangement Review, Spring, 1992.

YAZGAN, Teoman, Türkiye'de Bankacılık Sistemi, Reklam Yayınları:33, İstanbul, Eylül 2002.

YÜKSEL, Ali Sait, YÜKSEL, Aslı, YÜKSEL, Ülkü, Banka Yönetimi El Kitabı, Alfa Yayınları, İstanbul, 2002.

YÜKSEL, Berrin, ÖZKARA, Belk1s, Afyon Mermer Sektörünün Rekabet Analizi, Afyon, 1999. 